\section{Large Single-head Broccoli Yield as Affected by Plant Density, Nitrogen, and Cultivar in a Plasticulture System}

\author{
Daniel L. Schellenberg ${ }^{1}$, Anthony D. Bratsch ${ }^{2,4}$, and \\ Zhengxing Shen $^{3}$
}

AdDitional Index wORDs. Brassica olevacea var. italica, polyethylene mulch, spacing, fall production, plant population

Summary. An open-market window has been identified in Virginia for fall broccoli (Brassica olevacea var. italica). Vegetable producers using plasticulture systems can capitalize on this opportunity by growing broccoli as a second crop after summer vegetables. The objective of this project was to evaluate suitability of two broccoli cultivars, Everest and Gypsy, for the fall production of large single-heads ( $>6$ inches in diameter) for the fresh market. Planting density and rate of nitrogen $(\mathrm{N})$ fertilizer $(25,60$, and $100 \mathrm{lb} /$ acre $\mathrm{N})$ effects on yield characteristics were evaluated in a plasticulture system during a 3-year study (2003-05) conducted with broccoli transplants at the Virginia Polytechnic Institute and State University Kentland Agricultural Research Farm near Blacksburg, VA. The percentage of large heads was cultivar, plant density, and $\mathrm{N}$ rate dependent. The midseason 'Gypsy' produced significantly higher total yield and head weight compared with the early-season 'Everest'. The optimum density to maximize floret production per area was 12,500 plants/acre and a supplemental $\mathrm{N}$ rate of $100 \mathrm{lb} / \mathrm{acre}$. This $\mathrm{N}$ rate significantly $(P<0.002)$ improved marketable yield, large head yield, and leaf $\mathrm{N}$ accumulation compared with the lower rates. The data indicate that the feasibility of growing fall broccoli using a plasticulture system depends on the number of large heads produced for the fresh market. This in turn will depend on the choice of cultivar, stand establishment, and the requirement for supplemental $\mathrm{N}$ fertilizer over the residual level available in the soil after the first crop.

I n Virginia, past research has identified an open-market window for fall broccoli (Sterrett et al., 1990). Because earlier studies demonstrated the feasibility of multicropping broccoli on plastic mulches (Burnette et al., 1993; Clough et al., 1990; Coffey and Ramsey, 1987), growers that invest in a plasticulture system can capitalize on this market opportunity by producing broccoli after summer vegetables. Due to seasonal production schedules, the use of transplants is recommended for uniform stand establishment (Elson et al., 1992; Sterrett et al., 1991). Furthermore, transplants allow for the production of large single-heads ( $>6$ inches diameter) preferred by consumers (Jett et al., 1995; Relf

${ }^{1}$ Department of Viticulture and Enology, University of California, Robert Mondavi Institute, Davis, CA 95616

${ }^{2}$ University of Illinois Extension, Effingham Extension Center, Effingham, IL 62401-1697

${ }^{3}$ Department of Horticulture, Virginia Polytechnic Institute and State University, 301 Saunders Hall, Blacksburg, VA 24061-0327

${ }^{4}$ Corresponding author. E-mail: bratsch@uiuc.edu. et al., 1990). As a result, growers supply a high-value fall product and use plastic and residual $\mathrm{N}$ fertilizer from summer production.

The feasibility of producing vegetable crops using new cultural practices requires an examination of basic production components. Broccoli cultivar selection can significantly impact yield, quality, and production schedule (Cutcliffe, 1975; Damato, 2000). Multicropping changes the grower approach to $\mathrm{N}$ management, which affects broccoli yield, leaf $\mathrm{N}$ accumulation, and $\mathrm{N}$ recovery (Sanders et al., 1993; Zebarth et al., 1995).
Furthermore, plant density impacts the quantity of marketable head and broccoli head-size (Chung, 1985; Jett et al., 1995). We conducted a 3 -year study to identify practices that maximize large, single-head broccoli production.

\section{Materials and methods}

Experiments were conducted in 2003, 2004, and 2005 at the Virginia Polytechnic Institute and State University, Kentland Agricultural Research Farm, near Blacksburg, VA, at elevation $\approx 2000 \mathrm{ft}$ on a Hayter loam soil (fine-loamy mixed, mesic Ultic Hapludaf, $\mathrm{pH}$ 6.8).

During 2003 and 2004, five transplant densities were tested using two broccoli cultivars, Everest (early, $49 \mathrm{~d}$ from transplanting) and Gypsy (midseason, 59 d), (Seedway Seed, Elizabethtown, PA). The 2005 experiment evaluated the interaction between planting density and nitrogen of 'Gypsy'. 'Gypsy' was chosen for the 2005 experiment based on its enhanced postharvest attributes (Reddy, 2004).

In 2003 and 2004, plant densities were 19,$425 ; 14,570 ; 11,735$; 9715; and 8095 plants/acre, and in 2005 , a low density of 7285 plants/ acre was added. In-row plant spacing was $9,12,15,18,21$, and 24 inches, respectively, using twin rows spaced 12 inches on the plasticulture bed. A split-block design was used with cultivar in 2003 and 2004, and nitrogen rate in 2005 as a main plot factors, and density as a subplot factor.

In the fall, a winter rye (Secale cereale 'Abruzzi') cover crop (Southern States, Richmond, VA) was established and grown through the spring. The cover crop was killed $\approx 8$ weeks before planting using paraquat (Gramoxone $^{\mathrm{TM}}$; Syngenta, Greensboro, $\mathrm{NC})$ at $0.06 \mathrm{gal} /$ acre. Experimental

\begin{tabular}{llll}
\hline $\begin{array}{l}\text { Units } \\
\begin{array}{l}\text { To convert U.S. to SI, } \\
\text { multiply by }\end{array}\end{array}$ & U.S. unit & SI unit & $\begin{array}{l}\text { To convert SI to U.S., } \\
\text { multiply by }\end{array}$ \\
\hline 0.4047 & acre $(\mathrm{s})$ & $\mathrm{ha}$ & 2.4711 \\
0.3048 & $\mathrm{ft}$ & $\mathrm{m}$ & 3.2808 \\
3.7854 & gal & $\mathrm{L}$ & 0.2642 \\
9.3540 & gal/acre & $\mathrm{L} \cdot \mathrm{ha}^{-1}$ & 0.1069 \\
2.54 & inch $(\mathrm{es})$ & $\mathrm{cm}$ & 0.3937 \\
0.4536 & $\mathrm{lb}$ & $\mathrm{kg}$ & 2.2046 \\
1.1209 & $\mathrm{lb} / \mathrm{acre}$ & $\mathrm{kg} \cdot \mathrm{ha}^{-1}$ & 0.8922 \\
0.0254 & $\mathrm{mil}$ & $\mathrm{mm}$ & 39.3701 \\
2.2417 & ton $/ \mathrm{acre}$ & $\mathrm{Mg} \cdot \mathrm{ha}^{-1}$ & 0.4461 \\
$\left({ }^{\circ} \mathrm{F}-32\right) \div 1.8$ & ${ }^{\circ} \mathrm{F}$ & ${ }^{\circ} \mathrm{C}$ & $\left(1.8 \times{ }^{\circ} \mathrm{C}\right)+32$
\end{tabular}


sites were first disked to incorporate cover crop residues, left for 2 to 3 weeks, and then chisel plowed and disked again.

Before planting, soil samples were taken to determine $\mathrm{pH}$ and residual fertility. In 2003 and 2004, a bulk blend urea, diammonium phosphate, and potash (Southern States, Richmond, VA) amounting to $50 \mathrm{lb} /$ acre N, $75 \mathrm{lb} /$ acre phosphorus (P), and $200 \mathrm{lb} /$ acre potassium $(\mathrm{K})$ in 2003 and $150 \mathrm{lb} /$ acre K in 2004 was broadcast and incorporated by a tractor-mounted rototiller before bed formation. In 2005, 60 $\mathrm{lb} /$ acre $\mathrm{P}$ triple superphosphate and $175 \mathrm{lb} /$ acre K potash (Southern States) was applied and all $\mathrm{N}$ was injected through the drip system after planting to simulate conditions of succession planting where preplant $\mathrm{N}$ application was not feasible. Raised beds $2.5 \mathrm{ft}$ wide by 7 inches high were formed on 3-ft centers. Embossed black plastic ( 1.25 mil thickness) was laid over the bed with a single drip line $(0.45 \mathrm{gal} / \mathrm{min}, 1$-ft emitter spacing) installed 1 inch deep in the center of the bed.

Seeds were planted in 72 cell trays $(1.5 \times 1.5 \times 2.0$ inches $)$ containing a peat-based media (Superfine Germination Mix; Fafard, Concord, MA). Plants were grown 6 to 7 weeks under day temperatures of 25 to $30{ }^{\circ} \mathrm{C}$ and $20{ }^{\circ} \mathrm{C}$ night and were acclimated for $7 \mathrm{~d}$ in a sheltered outdoor area before planting. Planting dates were 28 Aug. 2003, 29 July 2004, and 4 Aug. 2005. Adverse weather conditions delayed the planting date in 2003. To ensure adequate stand establishment, any wilted or dead plants were replaced for up to $4 \mathrm{~d}$ after planting. However, due to extreme heat in 2005 and transplant loss, plants were replaced for up to $9 \mathrm{~d}$. A twin guard row was established on the outside of the plot area.

A single drip line, set between the twin rows, was used for irrigation and fertilizer delivery. Beginning 2 weeks after transplanting in 2003 and 2004, supplemental fertilizer (20N-8.7P-16.7K, Millers Soluble; Miller Chemical and Fertilizer, Hanover, PA) was injected five times resulting in a supplemental $\mathrm{N}$ application of $50 \mathrm{lb} /$ acre $\mathrm{N}$. In 2005, three $\mathrm{N}$ rates $(25,60$, and $100 \mathrm{lb} /$ acre) of the same source were split into seven weekly applications beginning 1 week after transplanting. Disease, insects, and weeds were controlled following standard pest management recommendations (Bratsch et al., 2003).

Harvest began 10 weeks after planting and continued for 2 to 3 weeks, totaling eight to nine harvests. Bead maturity and uniformity were the primary selection criteria for harvest. Leaves were removed and heads were cut to uniform lengths of 8 inches. Individual heads were sorted into marketable and cull yield. Culls included damaged heads and heads less than 3 inches in diameter. The marketable heads were further separated into large head category (> 6 inches in diameter). All marketable heads were cut and checked for hollow stem. In 2003 and 2004, effects on maturity by cultivar were evaluated using the percentage of heads harvested during the first harvest. Treatment effects on maturity were not evaluated in 2005 because of variable stand establishment and delayed replacements.
In 2005, 10 whole leaves were sampled from each treatment during early heading to compare $\mathrm{N}$ uptake under the $\mathrm{N}$ regimes. Leaves were dried at $80{ }^{\circ} \mathrm{C}$ and analyzed for percentage of $\mathrm{N}$ (A\&L Eastern Agricultural Laboratories, Richmond, VA).

Analyses of variance for yield data were completed with PROC GLM of SAS (SAS Institute, Cary, NC). Results are reported as significant when $P \leq 0.05$ for the least significant difference test.

\section{Results and discussion}

Cultivar efFects. In 2003, the heads were smaller and had less stem hollowness (Table 1). The later planting date in 2003 and cooler temperatures during the growth period likely slowed the rate of head development and affected its size and quality, similar to the experiment conducted by Cutcliffe (1972). In 2004, the average head diameter of cultivars Gypsy and Everest were close to the targeted size of 6 inches.

In 2003 and 2004, 'Gypsy' produced higher average head weights, but also had significantly greater stem hollowness than 'Everest'. However, in 2003, significant interactions between cultivar and plant density were observed for head weight $(P=$ 0.0043 ) and stem hollowness ( $P=$ 0.0077). 'Gypsy' at the lowest density had the highest head weight and stem hollowness (data not shown). A correlation between head weight and hollowness has long been documented (Zink, 1968). No such interactions occurred in 2004.

When selecting a cultivar, growers consider maximizing yield and

Table 1. Broccoli yield and stem hollowness, as affected by cultivar during 2003 and 2004 growing seasons at Blacksburg, VA.

\begin{tabular}{|c|c|c|c|c|c|c|}
\hline Cultivar & $\begin{array}{l}\text { Total yield } \\
{\text { (tons } / \text { acre })^{z}}\end{array}$ & $\begin{array}{c}\text { Marketable } \\
\text { yield }^{\mathrm{y}} \text { (tons/acre) }\end{array}$ & $\begin{array}{l}\text { Large yield }{ }^{\mathrm{x}} \\
\text { (tons/acre) }\end{array}$ & $\begin{array}{l}\text { Avg head } \\
\text { wt }(1 b)^{z}\end{array}$ & $\begin{array}{l}\text { Avg head diam } \\
\text { (inches) }^{\mathrm{z}}\end{array}$ & $\begin{array}{r}\text { Hollow } \\
\text { stem (\%) }\end{array}$ \\
\hline \multicolumn{7}{|c|}{2003} \\
\hline Gypsy & 4.9 & 4.6 & $2.8 \mathrm{~b}$ & $0.86 \mathrm{a}$ & $3.0 \mathrm{a}$ & $5 \mathrm{a}$ \\
\hline$P$ value & 0.460 & 0.860 & 0.025 & 0.008 & 0.004 & $<0.001$ \\
\hline \multicolumn{7}{|c|}{2004} \\
\hline$P$ value & 0.002 & 0.013 & 0.130 & $<0.001$ & 0.86 & $<0.001$ \\
\hline
\end{tabular}

${ }^{\mathrm{z}} \mathrm{l}$ ton $/$ acre $=2.2417 \mathrm{Mg} \cdot \mathrm{ha}^{-1}, \mathrm{l} \mathrm{lb}=0.4536 \mathrm{~kg}, \mathrm{l}$ inch $=2.54 \mathrm{~cm}$.

y Heads $>3$ inches diameter.

${ }^{x}$ Heads $>6$ inches diameter.

"Means within a column follow by different letters are significantly different at the $5 \%$ level according to the least significant difference test. 
Table 2. Broccoli yield and stem hollowness as affected by density, averaged across cultivars and 2003 and 2004 growing seasons at Blacksburg, VA.

\begin{tabular}{|c|c|c|c|c|c|c|}
\hline $\begin{array}{l}\text { Density } \\
(\text { plants/acre })^{\mathrm{z}}\end{array}$ & $\begin{array}{l}\text { Total yield } \\
{\text { (tons } / \text { acre })^{\mathrm{z}}}\end{array}$ & $\begin{array}{l}\text { Market yield } \\
\text { (tons/acre) }\end{array}$ & $\begin{array}{l}\text { Large yield } \\
\text { (tons/acre) }\end{array}$ & $\begin{array}{l}\text { Avg head } \\
w^{w}(1 b)^{z}\end{array}$ & $\begin{array}{c}\text { Avg head } \\
\text { diam (inches) }\end{array}$ & $\begin{array}{c}\text { Hollow } \\
\text { stem }^{\mathrm{w}}(\%)\end{array}$ \\
\hline 19,425 & $7.5 \mathrm{a}^{\mathrm{v}}$ & $2.8 \mathrm{a}$ & 0.9 & $0.62 \mathrm{~d}$ & $4.3 \mathrm{c}$ & 5 \\
\hline 14,570 & $7.0 \mathrm{ab}$ & $2.0 \mathrm{~b}$ & 1.1 & $0.76 \mathrm{c}$ & $4.4 \mathrm{bc}$ & 9 \\
\hline 11,735 & $6.4 \mathrm{bc}$ & $1.5 \mathrm{c}$ & 1.1 & $0.87 \mathrm{bc}$ & $4.6 \mathrm{abc}$ & 17 \\
\hline 9,715 & $6.0 \mathrm{c}$ & $1.2 \mathrm{~d}$ & 1.0 & $0.94 \mathrm{~b}$ & $4.8 \mathrm{a}$ & 14 \\
\hline 8,095 & $5.6 \mathrm{c}$ & $0.9 \mathrm{e}$ & 0.8 & $1.06 \mathrm{a}$ & $4.7 \mathrm{a}$ & 23 \\
\hline
\end{tabular}

${ }^{2} 1$ plant $/$ acre $=2.4711$ plants $/$ ha, 1 ton $/$ acre $=2.2417 \mathrm{Mg} \cdot \mathrm{ha}^{-1}, 1 \mathrm{lb}=0.4536 \mathrm{~kg}, \mathrm{l}$ inch $=2.54 \mathrm{~cm}$

'Heads $>3$ inches diameter.

Heads $>6$ inches diameter.

"Significant interaction occurred between cultivar and density in single year (2003) analysis.

${ }^{\vee}$ Means within a column follow by different letters are significantly different at the $5 \%$ level according to the least significant difference test.

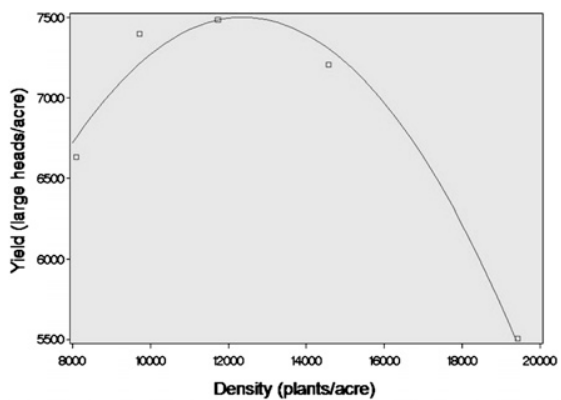

Fig. 1. Quadratic response of large broccoli head yield to plant density in 2003 and 2004 at Blacksburg, VA. The regression model was $\mathrm{Y}=1253+1.01 \mathrm{X}$ $-4.08 \times 10^{-5} \mathrm{X}^{2}\left(\mathrm{R}^{2}=0.98\right)$ where " $\mathrm{Y}$ " is number of large heads per acre and " $\mathrm{X}$ " is broccoli density. The maximum yield of 7500 large head per acre is obtained at $\approx 12,500$ plants /acre ( 1 plant or head per acre $=2.4711$ plants or heads per hectare).

marketability. In both years, the trend for early maturity of 'Everest' was evident (Table 1). With succession cropping, planting date can be variable, and cultivar maturity should be considered in relation to market timing and adverse fall growing temperatures. Earliness is often a sought after trait for marketability, however, studies in Virginia have shown a later market window has better prices (Sterrett et al., 1990). Furthermore, in a related study to test modifiedatmosphere packaging, 'Gypsy' displayed superior storage longevity and color retention (Reddy, 2004). Due to increased yield potential, marketability, and postharvest quality, despite increased stem hollowness, this study indicates 'Gypsy' as the preferred cultivar for fall broccoli production in plasticulture systems.

Table 3. Fall broccoli total yield and stem hollowness as affected by plant density and supplemental nitrogen (N) at Blacksburg, VA, during the 2005 growing season.

\begin{tabular}{|c|c|c|c|c|c|c|}
\hline \multirow{2}{*}{$\begin{array}{l}\text { Density (plants/acre })^{\mathrm{z}} \\
\text { N rate }(\mathrm{lb} / \text { acre }):^{\mathrm{z}}\end{array}$} & \multicolumn{3}{|c|}{$\begin{array}{l}\text { Total yield } \\
(\text { tons } / \text { acre })^{\mathrm{z}}\end{array}$} & \multicolumn{3}{|c|}{ Hollow stem (\%) } \\
\hline & 25 & 60 & 100 & 25 & 60 & 100 \\
\hline 19,425 & $3.2^{\mathrm{y}}$ & 3.4 & $4.4 \mathrm{ab}$ & $8 \mathrm{c}$ & $11 \mathrm{~d}$ & $29 \mathrm{~d}$ \\
\hline 14,570 & 3.0 & 4.0 & $5.0 \mathrm{a}$ & $13 \mathrm{c}$ & $40 \mathrm{c}$ & $50 \mathrm{c}$ \\
\hline 11,735 & 3.2 & 3.9 & $4.1 \mathrm{ab}$ & $39 \mathrm{~b}$ & $49 \mathrm{bc}$ & $59 \mathrm{bc}$ \\
\hline 9,715 & 3.0 & 3.7 & $3.7 \mathrm{~b}$ & $42 \mathrm{~b}$ & $53 \mathrm{~b}$ & $70 \mathrm{ab}$ \\
\hline 8,095 & 2.8 & 3.6 & $4.1 \mathrm{ab}$ & $49 \mathrm{~b}$ & $78 \mathrm{a}$ & $79 \mathrm{ab}$ \\
\hline 7,285 & 3.2 & 3.2 & $3.8 \mathrm{~b}$ & $73 \mathrm{a}$ & $72 \mathrm{a}$ & $83 \mathrm{a}$ \\
\hline$P$ value & NS & NS & 0.0198 & $<0.001$ & $<0.001$ & $<0.001$ \\
\hline
\end{tabular}

${ }^{\mathrm{z}} \mathrm{l}$ plant $/$ acre $=2.471 \mathrm{l}$ plants $/ \mathrm{ha}, \mathrm{l} \mathrm{lb} / \mathrm{acre}=1.1209 \mathrm{~kg} \cdot \mathrm{ha}^{-1}, \mathrm{l}$ ton $/$ acre $=2.2417 \mathrm{Mg} \cdot \mathrm{ha}^{-1}$.

${ }^{y}$ Means within a column follow by different letters are significantly different at the $5 \%$ level according to the least significant difference test.

Density efFeCTs. In 2003 and 2004, total yield was higher under higher densities (Table 2). Other studies confirm our results; higher yield with higher densities but with a trend for smaller heads (Chung, 1985; Palevitch, 1970; Zink and Akana, 1951). In addition, average head weight, average head diameter, and stem hollowness increased under the lower plant densities (Table 2). Under conditions of lower competition, faster plant growth and stem and head expansion rates have been speculated as reasons for increased hollowness (Cutcliffe, 1972). Stem hollowness appears to be a quality tradeoff for larger head development.

Recommendations for planting densities must achieve an efficient use of space. As a result, the primary objective of our study was to optimize the number of large heads of broccoli in a plasticulture system. Planting density determines plant populations, thus impacting the amount of space available for plant development. In 2003 and 2004, the combined result of 7,500 large heads/acre peaked at $\approx 12,500$ plants/acre when analyzed with regression analysis (Fig. 1). On raised open soil beds, Jett et al. (1995) reported highest single-head broccoli yields under at 14,570 plants/acre.

Nitrogen EFFeCts. Although numerous $\mathrm{N}$ fertility trials have been reported on broccoli, comparison, interpretation, and extrapolation of the results can be difficult due to different geographic locations, soil, weather, and crop management systems (Kowalenko and Hall, 1987). Significant interactions between density and $\mathrm{N}$ were observed for total yield $(P=0.0260)$ and stem hollowness $(P=0.0330)$. At low and middle $\mathrm{N}$ rates, there was no difference between total yield under the density gradient. However, the highest $\mathrm{N}$ rate appeared to have increased total yield under increasing density and stem hollowness increased under high $\mathrm{N}$ and low plant densities (Table 3 ). Increased $\mathrm{N}$ fertility has been shown to moderate the reduction of head weight 
Table 4. Fall broccoli yield, quality, and leaf nitrogen as affected by applied nitrogen $(\mathrm{N})$ at Blacksburg, VA, during 2005 growing season.

\begin{tabular}{lccccc}
\hline $\begin{array}{l}\text { N rate } \\
(\mathbf{l b} / \text { acre })^{\mathrm{z}}\end{array}$ & $\begin{array}{c}\text { Marketable } \\
\text { yield }^{\mathrm{y}} \\
\text { (tons } / \text { acre) }^{\mathrm{z}}\end{array}$ & $\begin{array}{c}\text { Large yield } \\
\text { (tons/acre) }^{\mathrm{x}}\end{array}$ & $\begin{array}{c}\text { Avg head } \\
\mathbf{w t}(\mathbf{l b})^{\mathrm{z}}\end{array}$ & $\begin{array}{c}\text { Avg head } \\
\text { diam } \\
\text { (inches) }^{\mathrm{z}}\end{array}$ & $\begin{array}{c}\text { Leaf } \\
\text { nitrogen } \\
(\%)\end{array}$ \\
\hline 25 & $2.8 \mathrm{~b}^{\mathrm{w}}$ & $0.7 \mathrm{c}$ & $0.59 \mathrm{c}$ & $5.3 \mathrm{~b}$ & $3.5 \mathrm{~b}$ \\
60 & $3.3 \mathrm{~b}$ & $1.2 \mathrm{~b}$ & $0.70 \mathrm{~b}$ & $5.6 \mathrm{ab}$ & $4.2 \mathrm{a}$ \\
100 & $4.1 \mathrm{a}$ & $2.0 \mathrm{a}$ & $0.79 \mathrm{a}$ & $5.7 \mathrm{a}$ & $4.4 \mathrm{a}$ \\
$P$ value & 0.002 & 0.002 & 0.003 & 0.030 & 0.002 \\
\hline
\end{tabular}

${ }^{\mathrm{z}} \mathrm{l} \mathrm{lb} / \mathrm{acre}=1.1209 \mathrm{~kg} \cdot \mathrm{ha}^{-1}$, l ton $/ \mathrm{acre}=2.2417 \mathrm{Mg} \cdot \mathrm{ha}^{-1}, \mathrm{l} \mathrm{lb}=0.4536 \mathrm{~kg}, \mathrm{l}$ inch $=2.54 \mathrm{~cm}$.

yeads $>3$ inches diameter.

${ }^{x}$ Heads $>6$ inches diameter.

${ }^{\text {w}}$ Means within a column follow by different letters are significantly different at the $5 \%$ level according to the least significant difference test.

associated with high plant populations (Dufault and Waters, 1985).

In 2005, higher supplemental $\mathrm{N}$ rates increased marketable and large head yield. Average head weight and diameter were increased with higher $\mathrm{N}$ rates (Table 4). These results are consistent with other studies that reported that $\mathrm{N}$ had the most marked effect on marketable yield (Cutcliffe, 1971; Kahn et al., 1991; Zink and Akana, 1951) and stem hollowness (Hipp, 1974; Tremblay, 1989). The improved yield parameters associated with higher $\mathrm{N}$ rates are supported by the higher percentage of $\mathrm{N}$ accumulation in leaf tissue (Table 4). Nitrogen accumulation in the aboveground portion of the plant increases with increasing rate of $\mathrm{N}$ fertilizer (Everaarts and De Willigen, 1999; Zebarth et al., 1995). In a study by Kowalenko and Hall (1987), high N rates significantly increased $\mathrm{N}$ in the leaf tissue and broccoli head without stimulation of the vegetative growth.

Data from 2003 and 2004 identify that a plant density of 12,500 plants / acre produces 7,500 large singleheads/acre in a twin-row plasticulture system. In addition, conditions for maximizing large head development also promote stem hollowness. In 2005 , the lower-than-expected yields were a result of simulating a multicropping environment where broadcast preplant $\mathrm{N}$ application is prohibitive. Further research is needed to refine $\mathrm{N}$ inputs and predict yield response of broccoli at the recommended densities following various seasonal fertility regimes in selected summer vegetables.

\section{Literature cited}

Bratsch, A.D., T.P. Kuhar, S.B. Phillips, S.B. Sterrett, C. Waldenmeier, and H.P. Wilson. 2003. Commercial vegetable production recommendations. Virginia Coop.
Ext. Publ. 420-456. Virginia Polytechnic and State University, Blacksburg.

Burnette, R.R., D.L. Coffey, and J.R. Brooker. 1993. Economic implications of nitrogen fertilization, drip irrigation, and plastic culture on cole crops and tomatoes grown sequentially. Tennessee Farm Home Sci. 168:5-13.

Chung, B. 1985. The effects of sowing time and plant density on the once-over harvest yield of broccoli. J. Hort. Sci. 60: 57-64.

Clough, G.H., S.J. Locascio, and S.M. Olson. 1990. Yield of successively cropped polyethylene-mulched vegetables as affected by irrigation method and fertilization management. J. Amer. Soc. Hort. Sci. 115:884-887.

Coffey, D.L. and P.W. Ramsey. 1987. Sequential cropping of vegetables on black plastic. Tennessee Farm Home Sci. 144:19-21.

Cutcliffe, J. 1971. Effects of plant population, nitrogen and harvest date on yield and maturity of single-harvested broccoli. HortScience 6:482-484.

Cutcliffe, J. 1972. Effects of plant spacing and nitrogen on incidence of hollow stem in broccoli. Can. J. Plant Sci. 52:833-834.

Cutcliffe, J. 1975. Effect of plant spacing on single-harvest yields of several broccoli cultivars. HortScience 10:417-419.

Damato, G. 2000. Late sowing dates and high plant density in six cultivars of broccoli for processing. Acta Hort. 533:267274.

Dufault, R.J. and L. Waters. 1985. Interaction of nitrogen fertility and plant populations on transplanted broccoli and cauliflower yields. HortScience 20:127128.

Elson, M.K., R.D. Morse, D.D. Wolf, and D.H. Vaughan. 1992. High-temperature inhibition of seed germination and seedling emergence of broccoli. HortTechnology $2: 417-419$.
Everaarts, A.P. and P. De Willigen. 1999. The effect of nitrogen and the method of application on yield and quality of broccoli. Netherlands J. Agr. Sci. 47:123-133.

Hipp, B. 1974. Influence of nitrogen and maturity rate on hollow stem in broccoli. HortScience 9:68-69.

Jett, L.W., R.D. Morse, and C.R. O'Dell. 1995. Plant-density effects on single-head broccoli production. HortScience 30:50-52.

Kahn, B., P. Shilling, G. Brusewitz, and R. McNew. 1991. Force to shear the stalk, stalk diameter, and yield of broccoli in response to nitrogen fertilization and within-row spacing. J. Amer. Soc. Hort. Sci. 116:222-227.

Kowalenko, C.G. and J.W. Hall. 1987. Effects of nitrogen applications on directseeded broccoli from a single harvest adjusted for maturity. J. Amer. Soc. Hort. Sci. 112:9-13.

Palevitch, D. 1970. Effects of plant population and pattern on yield of broccoli. HortScience 5:230-231.

Reddy, Y.V.R. 2004. Postharvest treatments effects on crown-cut broccoli shelf life. Virginia Polytechnic and State University, Blacksburg, Masters Thesis.

Relf, D., C.R. Odell, and M. Kushad. 1990. Virginia master gardeners reveal preferences in broccoli survey. HortScience 25:706.

Sanders, D.C., O.A. Bandele, C.H. Miller, and A. Nash. 1993. Nitrogen uptake within sequential vegetable cropping systems. J. Plant Nutr. 16:1119-1136.

Sterrett, S.B., C.W. Coale, and C.P. Savage. 1991. Comparison of management techniques for broccoli production using a systems-approach. HortScience 26:599602 .

Sterrett, S.B., J.W. Mapp, and C.W. Coale. 1990. Feasibility of broccoli as a new enterprise: A systems approach. HortScience 25:638-641.

Tremblay, N. 1989. Effect of nitrogen sources and rates on yield and hollow stem development in broccoli. Can. J. Plant Sci. 69:1049-1053.

Zebarth, B., P. Bowen, and P. Toivonen. 1995. Influence of nitrogen-fertilization on broccoli yield, nitrogen accumulation and apparent fertilizer-nitrogen recovery. Can. J. Plant Sci. 75:717-725.

Zink, F.W. 1968. Hollow stem in broccoli. Calif. Agr. 22:8-9.

Zink, F.W. and D.A. Akana. 1951. The effect of spacing on the growth of sprouting broccoli. Proc. Amer. Soc. Hort. Sci. 58:160-164. 